\title{
The Construction of New Business Format Marketing Strategy and Price Strategy Model
}

\author{
Weisheng Wen ${ }^{1}$, Qiongwei Luo ${ }^{1} \&$ Quansi Wen ${ }^{2}$ \\ ${ }^{1}$ School of Management and Information, Guangzhou Huali Science And Technology Vocational College, Guangzhou, \\ China \\ ${ }^{2}$ School of Computer Science \& Engineering, South China University of Technology, Guangzhou, China \\ Correspondence: Qiongwei Luo, School of Management and Information, Guangzhou Huali Science and Technology \\ Vocational College, Guangzhou 511325, China. Tel: 86-137-1149-2007.
}

Received: November 2, 2018

Accepted: November 22, 2018

Online Published: November 27, 2018

doi:10.5430/jms.v9n4p62

URL: https://doi.org/10.5430/jms.v9n4p62

\begin{abstract}
Under the background of Internet plus in contemporary China, new retail format of Online To Offline (O2O) has become the new engine of China's economic innovation and development. The new format marketing strategy has become the new focus of the market. A strategic model that can be applied to the pricing of online and offline products is an indispensable element of the corporate marketing strategy. This paper takes the $\mathrm{O} 2 \mathrm{O}$ new retail format price strategies of Dama and Yongsheng as the research background and re-examines the influencing factors in the western price theory system. Based on the pricing model applicable to commercial enterprises, this paper discusses the theory of the construction of the price strategy model with the $\mathrm{O} 2 \mathrm{O}$ new retail format. Through the high participation of enterprises, and the discussion and test of the theoretical model with the enterprise, the theoretical models are given higher value.
\end{abstract}

Keywords: new retail format, $\mathrm{O} 2 \mathrm{O}$, internet plus, price strategy model

\section{Introduction}

$\mathrm{O} 2 \mathrm{O}$, namely Online to Offline, refers to the combination of offline business opportunities and the Internet, making the Internet a front-end for offline transactions. Only the online sales volume of JD, which is the China's largest self-operated e-commerce company, reached 127.1 billion yuan on the "Double 11" shopping festival in 2017, and Tmall, the largest business-to-consumer shopping site of China, reached 168.2 billion yuan on that day, far exceeding the annual GDP of countries such as Iceland and Cameroon. It can be foreseen that in the Internet plus era, in the new $\mathrm{O} 2 \mathrm{O}$ retail format, the price sensitivity of consumers is gradually strengthened. Both online price setting and offline price setting have put forward higher requirements for enterprises. In the 1980s, and even earlier, experts and scholars began to propose price competition models and pricing strategies. While with the constant changes in the times and business formats, there are new requirements for price models and pricing strategies. The price strategy model had to begun a new revolution. In order for a company to play a very competitive role in the new format of China today, an efficient and applicable $\mathrm{O} 2 \mathrm{O}$ pricing strategy model is indispensable.

This research is a joint research project between the school and the enterprise, such as the Dama and Yongsheng (the companies' names use the pseudonyms).

Dama, founded in Guangzhou in 2014, has a registered capital of 16 million. It is a Sino-foreign joint venture with Sinicism organic concept of $\mathrm{O} 2 \mathrm{O}$ agricultural brand enterprise. Dama aims to bring China's healthiest farm products to consumers and to spread the concept of health. Since its inception, the company has been committed to bringing the most natural foods of the farmer to consumers in order to create a Chinese-style organic concept brand. The research data in this study comes from the new retail brand Dama Community Chain Store (DCCS) under the Dama company. While working hard to create a consumer atmosphere of offline warmth and fashion, DCCS is also striving to build efficient and fast consumption channels online, and to provide customers with comfortable and convenient consumer experience. While providing customers with foodstuffs, it also provides customers with rich and accurate dietary health information, and strives to create a special food and food enterprise integrating online and offline.

Yongsheng Supermarket was established in 1998, is a private joint-stock large-scale enterprise group cultivated by 
Fujian Province in the process of promoting the transformation of traditional farmer's market to modern circulation. It is one of the first circulation enterprises in mainland China to introduce fresh agricultural products into modern supermarkets. It is headquartered in Fuzhou City, Fujian Province. Yongsheng Supermarket is one of the top 500 enterprises in China. It is a national leading enterprise of "circulation" and "agricultural industrialization". It has won the "China Well-known Trademark" and listed on the Shanghai Main Board. The State Council awarded the "National Employment Advanced Enterprise", and Yongsheng won the "National May 1st Labor Award" and other honorary titles as well. On December 22, 2017, Yongsheng Supermarket received a 12\% stake in the Red Flag chain and became a comprehensive strategic partner. On January 23, 2018, French retailer Carrefour announced that Tencent and Yongsheng will make potential investments in Carrefour China, and Carrefour and Tencent have reached a strategic cooperation agreement in China.

The first purpose of this study is to empirically explore the value and threat factors of $\mathrm{O} 2 \mathrm{O}$ products pricing based upon the integrative perspective of Internet plus and new retail format. The second is to provide an efficient price model for enterprises with new retail format. Then, through the application and comparison of the model by two new retail companies, the practicality of the model is tested.

The next section introduces related literature. The model construction and model application results, discussions are presented in the following sections. The final section explains the limitations of this study and proposes further research directions.

\section{Literature Review}

\subsection{Price Strategy and Price Model}

The formation of the price strategy was mainly due to the development of large-scale retail industry at the end of the 19th century, and the company began to study the pricing strategy of selling products. In most cases, price is at the main stage of making a choice as a buyer. In the last ten years, the emergence of Internet plus in China has brought about the emergence of new commercial retail formats. The marketing mix of online to offline products has provided new research implications for corporate price strategies. However, price is still the only factor that can generate profits, and the importance of price strategy is still very significant.

The marketing factor of "pricing strategy" first appeared in the concept of marketing mix. And the concept of marketing mix was first adopted by Harvard University professor N.H. Borden in 1964. Later, Professor R. Clivet summarized the marketing mix elements into products, pricing, place, and promotions (4Ps). In 1967, the father of marketing, P. Kotler, further analyzed the concept of "marketing mix" in the book "Marketing Management" and proposed a deeper understanding of the pricing strategy. In 1979, H. Simon proposed a dynamic model of price elasticity associated with the brand life cycle. This study found that it is important for companies to formulate optimal pricing policies based on changes in price elasticity. In 1981, R. J. Dolan and A. P. Jeuland proposed an optimal price model that takes into account the dynamics of cost and diffusion process. They studied the optimal price problem under static demand and dynamic demand. The Dolan-Jeuland model reflects the time trajectory of the optimal price during the planning period, which is of great significance for innovative enterprises to flexibly choose the penetration strategy and the fat-removing strategy in the fierce competition. The theoretical model of competitiveness proposed by Professor M. E. Porter required that companies must obtain cost leadership within the industry and turn cost advantages into price advantages, while, low prices often become the only choice for corporate pricing. In 2016, Z. He, T. C. E. Cheng, J.C. Dong, S. Y. Wang proposed an agent-based competitive O2O model (ACOM), to investigate the evolutionary location and pricing behaviours of service merchants. In 2017, Z. F. Zhao, W. Liu and F. Bo proposed a model to analyze whether the service provider with asymmetric capability, in the O2O business model, should sign contracts with the agency, using the "release price" to sell opaque services, in opaque distribution channels.

\section{$2.2 \mathrm{O} 2 \mathrm{O}$ and New Business Format}

T. Ahn, S. Ryu and Ingoo Han, in 2004, proposed the Internet shopping mall consumers considerd the Web site was a virtual store, whose functions just like the brick-and-mortar companies' functions, rather than a simple information system. In 2015, S.S. Xiao and M. Dong suggested that a new e-comerce model called online to offline (O2O) e-comerce that consumers searched and booked products/services online before consuming them in brick-and-mortar companies, had received significant attention. It can be concluded from Z. He and T.C.E. Cheng that there are more competitors entering the $\mathrm{O} 2 \mathrm{O}$ markets, which lead to more difficult for enterprises to attract customers in the online-to-offline $(\mathrm{O} 2 \mathrm{O})$ business. While, it was necessary for enterprise to optimize the combined pricing-location decision to create and keep sustainable competitive advantage in competitive O2O markets. In 2017, D. Grewal, A. L. 
Roggeveen and J. Nordfält proposed that, today, with the new business format — "new retail", consumers are already tired of the "preferential" and "price reduction" bombings, the "low price" was not the best pricing strategy for enterprises to choose.

\subsection{Summary}

In view of above observations, the authors put the price into one of the most necessary place in $\mathrm{O} 2 \mathrm{O}$ marketing. While the previous researches on the price model provided powerful insights into the pricing of companies in different environments. However, the scope of the model application proposed in the study is limited, and it cannot be applied to the pricing of its $\mathrm{O} 2 \mathrm{O}$ products by a wide range of Internet plus enterprises.

On the basis of previous studies, this topic focuses on the formulation of online to offline product pricing strategies for enterprises under the "Internet plus" in contemporary China. By constructing the $\mathrm{O} 2 \mathrm{O}$ price strategy model, it will provide a more practical and efficient pricing strategy for Chinese contemporary new format enterprises. Therefore, the price discomfort of enterprises in various industries in the new business mode can be further solved, thereby improving the core competitiveness of the enterprise.

\section{Research Methodology}

This study is mainly about, in the context of "Internet+" in China, the research on the price strategy of the new business format and new retail model. With the emergence of new business, the price strategy model and marketing strategy of online and offline products have changed, while the application of the new business format's online and offline marketing mix, and its price strategy model, has encountered problems in practice. Due to the limitations of the theories, this study focuses on the $\mathrm{O} 2 \mathrm{O}$ new retail price strategy, re-examines the influencing factors in the Western price theory system, and exploring and constructing the general theory of price strategy model of O2O new retail model. This study adopts empirical research, through the methods such as model constructing, case analysis and practice comparison, mathematical analysis, from individual to general, and from general to individual. While, using modern economic research methods, make the study have strong theoretical interpretation and accuracy, and at the same time can withstand the test of practice. The narrative method of this study will use the combination of abstraction and concrete, and the combination of theory and application.

\section{Model Description}

\subsection{The Influence of O2O Price Strategy on Enterprises}

Standing on the $\mathrm{O} 2 \mathrm{O}$ pricing model and price strategy, the enterprise pricing is not just a price tag to the products. First of all, price strategy shows the basis of a product price, with the fluctuations of online price and offline price, the price as the main means of resources allocation, the price strategy becomes a magic weapon for enterprises to profit, and the price war has been ubiquitous since the beginning of the 20th century in China. Price is a major factor in making purchase choices for buyers, and non-price factors are also a major factor influencing people's purchases today. However, in the marketing mix, the price is the only factor that can make a profit for the enterprise, and its sensitivity is still the most active factor in the market to date.

The impact of marketing goals. Under the conditions of the market economy, before the actual pricing, the enterprise is generally guided by the overall marketing target of the enterprise. If the product is developed an $\mathrm{O} 2 \mathrm{O}$ price strategy, first of all, the strategy must be consistent with the strategic goals of the company and serve the strategic goals of the enterprise. Commodity pricing usually chooses the maximum profit margin, maintains or expands market share, the strongest competitiveness, the highest return on investment, et cetera, creating or striving for a business environment conducive to enterprises development. Due to the changing environment and the enterprise's strengths, weaknesses, opportunities and threats (SWOT), the specific target orientation of the enterprise pricing is also diverse. Different companies and different product target orientations are obviously different. Even in the same enterprise, the market environment encountered in different periods is different, and the set pricing targets are different. When setting pricing targets, enterprises should maintain the flexibility of pricing tactics, pricing methods, and techniques based on changes in the environment and around marketing objectives.

The impact of cost. Whether it is online or offline, a low-cost product of the company, especially in comparison with competitors, is competitive. It is also the most convincing signal that the company's products are strong or fragile. Cost is the reference value that determines the price floor when pricing, which reflects the basic value of the product. Price-cost comparison plays a crucial role in product competition in the industry. Cost-price competition is usually the most important market factor, and low-cost always can prevail. In the pricing of enterprises, in addition to product cost control, it is necessary for enterprises to comprehensively consider the trend of various types of costs. Therefore, it is necessary to analyze the law of cost changes in the industry-experience curve. Since the increase in 
cumulative output will reduce the cost per unit of product, that is, when the enterprise has mastered the experience, it can improve the operation method, and reduce the unit cost of the product by introducing advanced equipment and scientific management methods.

The impact of demand. Consumers' perception of the value of a product comes from the demand for the product. At the same time, the customer-perceived value also determines the price ceiling of the product. While the final price of the product is in line with the market competition and fluctuates between the price ceiling and the price floor. Typically, companies develop online and offline pricing strategies through an analysis of the price elasticity of demand. After a company sets a price for a certain product, it does not mean that it is done. The current price of the enterprise is not static but needs to be constantly adjusted as the marketing environment changes. Usually, the price elasticity of demand directly affects the marginal revenue of the product, so it will affect the profit of the company to a large extent. In fact, the demand situation of different products will certainly be different. When the products sold by the company have certain price elasticity, the pricing level of the enterprise is particularly important because the price of this product will directly affect the sales volume of the product. This directly determines whether the company is profitable or losing money.

The impact of competition. The competitive profile has a huge impact on pricing. Whether online or offline, all companies must consider the SWOT formed by the competition between the competitive environment and competitors, in order to find the correct pricing tactics and price strategy. For price changes, it is recommended to rely on the response to competitors, especially when competing for the same target market, the response of competitors will be quite large, and have to analyze the competitor's SWOT and study the reaction of opponents in past price competition. It is also possible to determine the competitor's response to the company's price reduction or price increase through relevant intelligence or statistical analysis. The enterprise determines the appropriate price of its own products based on the changes in the competitive elements of similar products on the market. If the company is in a fiercely competitive market, but the product is less differentiated, the company cannot have a high degree of autonomy when setting prices. On the contrary, companies need to refer to the price of similar products on the market to a large extent, especially to actively understand the price of the competitor's products and the characteristics of their products. According to the environment and SWOT changes, companies should have an accurate strategic positioning to develop a final price that can adapt to the market and earn profits.

\subsection{Overall Structure of the O2O Price Strategy Model}

After the implementation of reform and opening in China, the concept of "marketing" began to be introduced. The market economy system was established in 1992, and the corresponding marketing concept was raised in China, and the price competition became increasingly fierce. China's corporate price strategy is inspired by the price strategy of Western companies, and it has undergone dramatic changes with the transformation of corporate marketing concepts. The transformations of China's marketing are from production concept, product concept, sales concept to marketing concept. The transformation of price strategy from high value low price, high value, and high price, selling pricing to price discrimination, a microeconomic pricing strategy that same or substantially similar products are traded at different prices by the same supplier in different markets. The price strategy is based on the strategic goals of the company, to grasp the competitive advantage for the enterprise. The price strategy is based on the strategic goals of the company, to grasp the competitive advantage for the enterprise. The core elements of the price strategy formed by mechanism creating value, customer perceived value, channel supply value, market sales value, technology leading value, after sales service value, etc. To gain a competitive advantage, enterprises must balance the strength and weakness of core elements, so that the core elements of price strategy become the new core competitiveness of enterprises. The metrics of the value factors of these six factors, mechanism creating value, customer perceived value, channel supply value, market sales value, technology leading value, after sales service value, are analyzed as (+) 0-6 points. Mechanism: The greater the flexibility of the enterprise mechanism, the higher the flattening, the higher the value coefficient. Customer perception: The stronger the customer's perceived value, the higher the recognition of the company, the higher the value coefficient. Channel: The stronger the channel circulation, the higher the accuracy of coverage, the higher the value coefficient. Market: The more successful a company's marketing, the higher the relative market share, the higher the value coefficient. Technology: The more advanced the enterprise technology, the harder it is to be imitated, the higher the value coefficient. After-sales: The more perfect the after-sales service, the better the customer experience, the higher the value coefficient. These six factors are affected by the SWOT of the enterprise, and the threat coefficient evaluation and analysis are analyzed by the corresponding six factors, industry volatility threats, supply dependence threats, product replacement threats, market preemption threats, customer bargaining threats (-) 0-6 points. Industry: the greater the fluctuation, the higher the threat coefficient. Suppliers: the stronger the enterprise's dependence on suppliers, the higher the threat coefficient. Substitutes: the more substitutes 
to an enterprise product, the stronger the substitutability, the higher the threat coefficient. Industry competitors: The more intense the market competition, the higher the threat coefficient. The perfect competition market is 6 , and the perfect monopoly market is 0 . Potential entrants: The greater the chance of potential entrants entering, the higher the chance of success, the higher the threat coefficient. Customer bargaining: The stronger the bargaining power of the customer, the buyers' market, the higher the threat coefficient. And five major levels of choice are a) coefficient analysis evaluation layer; b) coefficient accounting layer; c) pricing result output layer. d) pricing result evaluation layer; e) price determination/adjustment layer and proceed with the strategic deployment of the price.

\subsection{The Modely Layer}

\subsubsection{Coefficient Analysis Evaluation Layer}

- Value coefficient evaluation metric (+) 0-6 points

Mechanism: The greater the flexibility of the enterprise mechanism, the higher the flattening, the higher the value coefficient point.

Consumer perception: The stronger the customer's perceived value, the higher the recognition of the company, the higher the value coefficient point.

Channel: The stronger the channel circulation, the higher the accuracy of coverage, the higher the value coefficient point.

Market: The more successful a company's marketing, the higher the relative market share, the higher the value coefficient point.

Technology: The more advanced the enterprise technology, the harder it is to be imitated, the higher the value coefficient point.

After-sales: The more perfect the after-sales service, the better the customer experience, the higher the value coefficient point.

- Threat coefficient evaluation metric (-) 0-6 points

Industry: the greater the fluctuation, the higher the threat coefficient point.

Suppliers: the stronger the enterprise's dependence on suppliers, the higher the threat coefficient point.

Substitutes: the more substitutes to an enterprise product, the stronger the substitutability, the higher the threat coefficient point.

Industry competitors: The more intense the market competition, the higher the threat coefficient point.

Potential entrants: The greater the chance of potential entrants entering, the higher the chance of success, the higher the threat coefficient point.

Customer bargaining: The stronger the bargaining power of the customer, the buyers' market, the higher the threat coefficient point.

\subsubsection{Coefficient Accounting Layer}

- Outcome (O)

Outcome $(\mathrm{O})$ means the sum of coefficients. The characters, $\sum \mathrm{O}_{\mathrm{D}}$ and $\sum \mathrm{O}_{\mathrm{YS}}$, in the following mathematical formula, means the outcome of Dama's strategy model and the outcome of Yongsheng's strategy model respectively.

- Value Point (VP)

Mechanism creating value $\left(\mathrm{VP}_{\mathrm{MC}}\right)$, customer perceived value $\left(\mathrm{VP}_{\mathrm{CP}}\right)$, channel supply value $\left(\mathrm{VP}_{\mathrm{CS}}\right)$, market sales value $\left(\mathrm{VP}_{\mathrm{MS}}\right)$, technology leading value $\left(\mathrm{VP}_{\mathrm{TL}}\right)$, after sales service value $\left(\mathrm{VP}_{\mathrm{AS}}\right)$.

\section{- Threat Point (TP)}

Industry volatility threats $\left(\mathrm{TP}_{\mathrm{IV}}\right)$, supply dependence threats $\left(\mathrm{TP}_{\mathrm{SD}}\right)$, product replacement threats $\left(\mathrm{TP}_{\mathrm{PR}}\right)$, market pre-emption threats $\left(\mathrm{TP}_{\mathrm{MP}}\right)$, potential entrants threats $\left(\mathrm{TP}_{\mathrm{PE}}\right)$, customer bargaining threats $\left(\mathrm{TP}_{\mathrm{CB}}\right)$.

\section{- Coefficient weight (K)}

The six major value factors and the six major threat coefficients have corresponding weights, and the weight depends on the industry in which the enterprise is located. And it is determined by the enterprise. 


\subsubsection{Pricing Result Output Layer and the Mathematical Formula}

The core mathematical formula of this price model in this study is Summation.

$$
\begin{gathered}
\sum O=\sum V+\sum T \\
V=K \times V P \\
\sum V=K_{M C} \times V P_{M C}+K_{C P} \times V P_{C P}+K_{C S} \times V P_{C S}+K_{M S} \times V P_{M S}+K_{T L} \times V P_{T L}+K_{A S} \times V P_{A S} \\
T=K \times T P \\
\sum T=K_{I V} \times T P_{I V}+K_{S D} \times T P_{S D}+K_{P R} \times T P_{P R}+K_{M P} \times T P_{M P}+K_{P E} \times T P_{P E}+K_{C B} \times T P_{C B}
\end{gathered}
$$

There are respectively greater than zero, $\sum \mathrm{O}>0$, equal to zero, $\sum \mathrm{O}=0$, less than zero, $\sum \mathrm{O}<0$, which respectively constitute higher than the market average price pricing, adapt to the market average price pricing, lower than the market average price pricing, as the Table 1 shows.

Table 1. Price strategy advice

\begin{tabular}{ll}
\hline$\sum \mathrm{O}$ & Price Strategy Advice \\
\hline$\sum \mathrm{O}>0$ & Constitute higher than the market average price pricing \\
$\sum \mathrm{O}=0$ & Adapt to the market average price pricing \\
$\sum \mathrm{O}<0$ & Lower than the market average price pricing. \\
\hline
\end{tabular}

\subsubsection{Pricing Result Evaluation Layer}

The pricing results are mainly in four categories: high sales - high profit, low sales - high profit, low sales - low profit, high sales - low profit.

4.3.5 Price Determination / Adjustment Layer

Mainly pricing determination, reanalysis of accounting coefficient pricing.

As the Figure. 1 shown, it constitutes a pricing model.

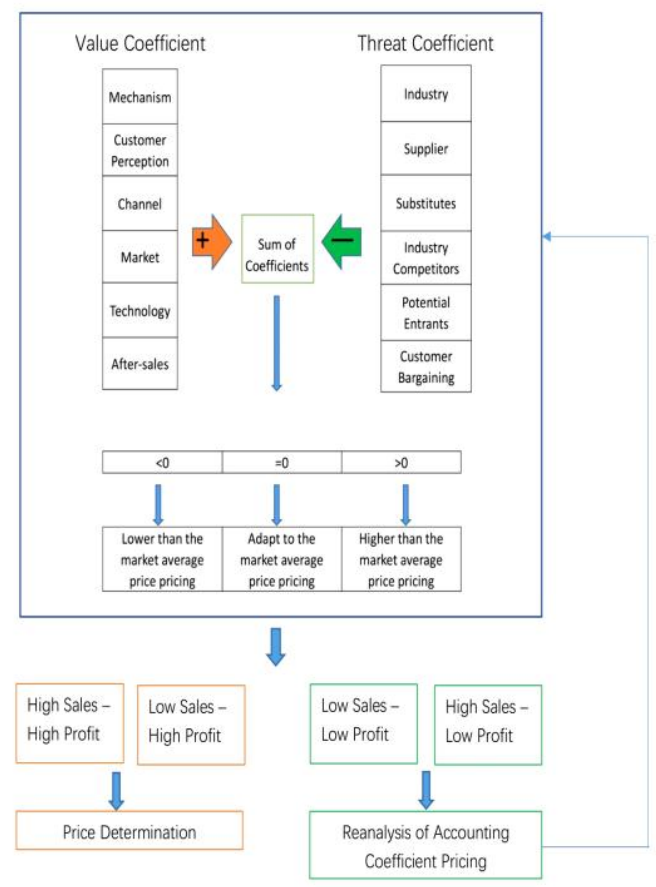

Figure 1. O2O price strategy model 


\section{The Practice of O2O Price Strategy Model - A Comparative Analysis of Dama's and Yongsheng's Price Strategy}

This study, as a subject of joint research and cooperation between schools and enterprises, analyzes the role of the competitiveness of the two companies, Dama and Yongsheng, on the price strategy model. Then, it evaluates the online and offline product pricing strategies of the two companies separately, and compares and analyzes the role of each composition, including the advantages and disadvantages, opportunities and threats, of the enterprise, in the price strategy model.

Both Dama and Yongsheng are our school-enterprise cooperative enterprises (the company name uses the pseudonym for short names). Through comparing the price competition strategies of the two companies over the past year, putting their major factor coefficients into the price strategy model for experimentation and practice. And by testing of the evaluation results of the online and offline pricing strategies of the two companies, to test the price strategy model.

\subsection{Price Strategy Model Applied to Dama}

Through the joint research and discussion with the related management and store managers of Dama, the coefficients and the corresponding weights were calculated. As shown in the following Figure 2, Figure 3 and Table 2, Table 3:

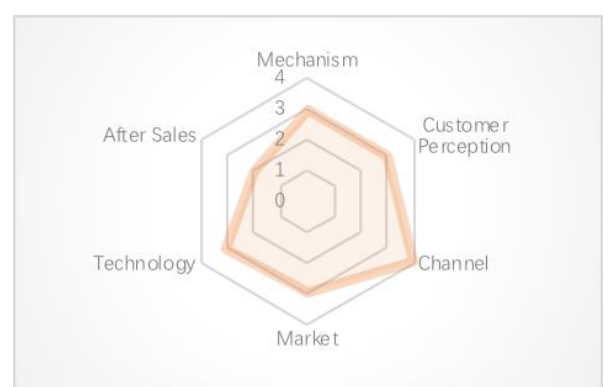

Figure 2. The VP of Dama's value elements

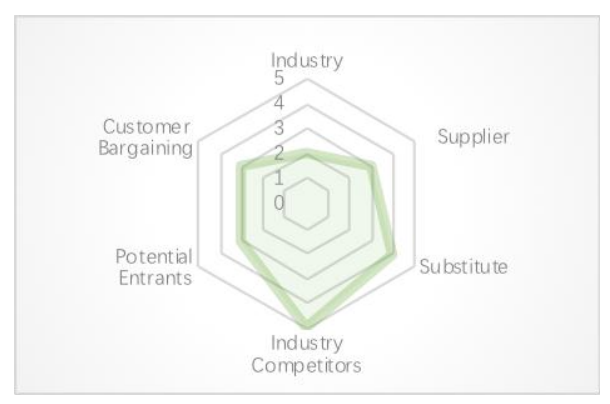

Figure 3. The TP of Dama's threat elements

Table 2. The value coefficient of Dama

\begin{tabular}{llrrr}
\hline & Element & Weight $(\mathrm{K})$ & $\mathrm{VP}$ & \multicolumn{1}{c}{$\mathrm{V}$} \\
\hline & Mechanism & 0.15 & 3 & 0.45 \\
\cline { 2 - 5 } Value Coefficient & Customer Perception & 0.20 & 3 & 0.60 \\
\cline { 2 - 5 } & Channel & 0.25 & 4 & 1.00 \\
\cline { 2 - 5 } & Market & 0.20 & 3 & 0.60 \\
\cline { 2 - 5 } & Technology & 0.10 & 3 & 0.30 \\
\cline { 2 - 5 } & After Sales & 0.10 & 2 & 0.20 \\
\cline { 2 - 5 } & $\sum \mathrm{V}$ & 1 & & 3.15 \\
\hline
\end{tabular}

$\sum \overline{V=K_{M C} \times V P_{M C}+K_{C P} \times V P_{C P}+K_{C S} \times V P_{C S}+K_{M S} \times V P_{M S}+K_{T L} \times V P_{T L}+K_{A S} \times V P_{A S}}$

$\sum V_{D}=0.15 \times 3+0.20 \times 3+0.25 \times 4+0.20 \times 3+0.10 \times 3+0.10 \times 2=3.15$

Table 3. The threat coefficient of Dama

\begin{tabular}{llllll}
\hline & Element & Weight $(\mathrm{K})$ & VP & \multicolumn{1}{c}{ V } \\
\hline & Industry & 0.10 & 2 & 0.20 \\
\cline { 2 - 5 } & Supplier & 0.25 & 3 & 0.75 \\
\cline { 2 - 5 } Threat Coefficient & Substitute & 0.15 & 4 & 0.60 \\
\cline { 2 - 5 } & Industry Competitors & 0.20 & 5 & 1.00 \\
\cline { 2 - 5 } & Potential Entrants & 0.10 & 3 & 0.30 \\
\cline { 2 - 5 } & Customer Bargaining & 0.20 & 3 & 0.60 \\
\cline { 2 - 6 } & $\sum \mathrm{T}$ & 1 & & 3.45 \\
\hline
\end{tabular}

$\sum \overline{T=K_{I V} \times T P_{I V}+K_{S D} \times T P_{S D}+K_{P R} \times T P_{P R}+K_{M P} \times T P_{M P}+K_{P E} \times T P_{P E}+K_{C B} \times T P_{C B}}$ 
$\sum T_{D}=0.10 \times 2+0.25 \times 3+0.15 \times 4+0.20 \times 5+0.10 \times 3+0.20 \times 3=3.45$

$\sum O=\sum V-\sum T$

$\sum O_{D}=3.15-3.45=-0.3<0$

Because $\sum \mathrm{O}_{\mathrm{D}}<0$, Dama should adopt a pricing strategy that is lower than the market average.

\subsection{Price Strategy Model Applied to Yongsheng}

Through the joint research and discussion with the relevant management, managers and related store managers of Yongsheng, the coefficients and the corresponding weights were calculated. As shown in the following Figure 4, Figure 5 and Table 4, Table 5:

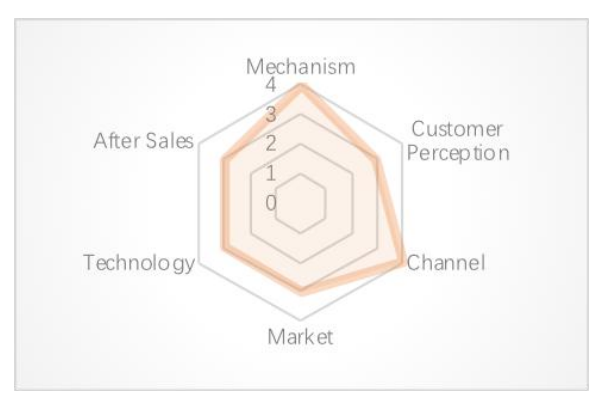

Figure 4. The VP of Yongsheng's value elements

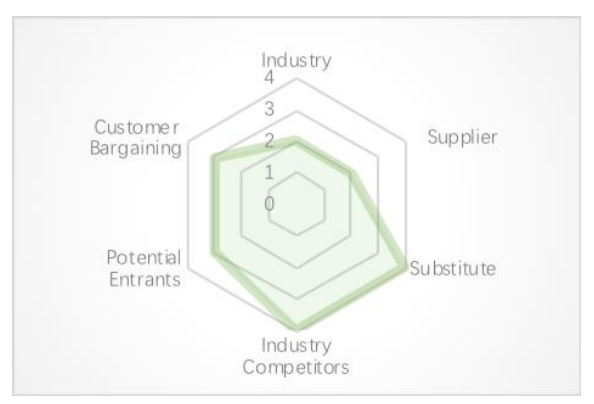

Figure 5. The TP of Yongsheng's threat elements

Table 4. The value coefficient of Yongsheng

\begin{tabular}{llllll}
\hline & \multicolumn{1}{l}{ Element } & Weight $(\mathrm{K})$ & $\mathrm{VP}$ & $\mathrm{V}$ & \\
\hline & Mechanism & 0.15 & 4 & 0.60 \\
\cline { 2 - 5 } & Customer Perception & 0.20 & 3 & 0.60 \\
\cline { 2 - 5 } Value Coefficient & Channel & 0.25 & 4 & 1.00 \\
\cline { 2 - 5 } & Market & 0.20 & 3 & 0.60 \\
\cline { 2 - 5 } & Technology & 0.10 & 3 & 0.30 \\
\cline { 2 - 5 } & After Sales & 0.10 & 3 & 0.30 \\
\cline { 2 - 5 } & $\sum \mathrm{V}$ & 1 & & 3.40 \\
\hline
\end{tabular}

$\overline{\Sigma V}=\mathrm{KMC} \times \mathrm{VPMC}+\mathrm{KCP} \times \mathrm{VPCP}+\mathrm{KCS} \times \mathrm{VPCS}+\mathrm{KMS} \times \mathrm{VPMS}+\mathrm{KTL} \times \mathrm{VPTL}+\mathrm{KAS} \times \mathrm{VPAS}$

$\sum \mathrm{VY}=0.15 \times 4+0.20 \times 3+0.25 \times 4+0.20 \times 3+0.10 \times 3+0.10 \times 3=3.40$

Table 5. The threat coefficient of Yongsheng

\begin{tabular}{llllll}
\hline & Element & Weight $(\mathrm{K})$ & VP & \multicolumn{3}{c}{ V } \\
\hline & Industry & 0.10 & 2 & 0.20 \\
\cline { 2 - 5 } & Supplier & 0.25 & 2 & 0.50 \\
\cline { 2 - 5 } Threat Coefficient & Substitute & 0.15 & 4 & 0.60 \\
\cline { 2 - 5 } & Industry Competitors & 0.20 & 4 & 0.80 \\
\cline { 2 - 5 } & Potential Entrants & 0.10 & 3 & 0.30 \\
\cline { 2 - 5 } & Customer Bargaining & 0.20 & 3 & 0.60 \\
\cline { 2 - 5 } & $\sum \mathrm{T}$ & 1 & & 3.00 \\
\hline
\end{tabular}

$\sum \mathrm{T}=\mathrm{KIV} \times \mathrm{TPIV}+\mathrm{KSD} \times \mathrm{TPSD}+\mathrm{KPR} \times \mathrm{TPPR}+\mathrm{KMP} \times \mathrm{TPMP}+\mathrm{KPE} \times \mathrm{TPPE}+\mathrm{KCB} \times \mathrm{TPCB}$

$\sum \mathrm{TY}=0.10 \times 2+0.25 \times 2+0.15 \times 4+0.20 \times 4+0.10 \times 3+0.20 \times 3=3.00$

$\sum \mathrm{O}=\sum \mathrm{V}+\sum \mathrm{T}$

$\sum \mathrm{OY}=3.40-3.00=0.4>0$

Because $\sum \mathrm{OY}>0$, Yongsheng should adopt a pricing strategy that is higher than the market average. 


\subsection{A Comparative Analysis of Aunt's Price Strategy and Yongsheng's Price Strategy}

From the application results of A and B, it can be concluded that Dama should change the current price competition strategy, and adopt a price strategy that is lower than the market average price in similar products to consolidate market share, and pay attention to the promotion of personalized products, change the current product positioning, and dock the target market. While, Yongsheng should maintain its current competitive advantage, in line with the market's average pricing price strategy, launch a new format with more advantages, accelerated occupy the market and become the leader of the new retail format. However, in the actual pricing process of the two companies, it can be found that both the Dama's pricing and Yongsheng's pricing are higher than the market average pricing. In order to test the practical accuracy of the $\mathrm{O} 2 \mathrm{O}$ pricing model, the sales performance of Dama and Yongsheng in the past four quarters are compared in the Figure 6.

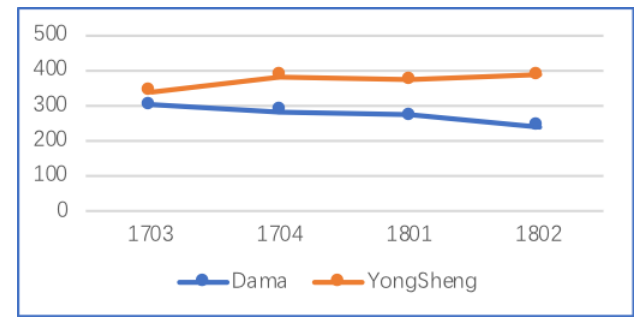

Figure 6. The comparation of Dama's and Yonsheng's sales performance

As shown in Figure 6, it can be clearly seen that Dama's sales performance is declining, and its total performance is much lower than Yongsheng's, while Yongsheng has reached the peak performance and showed stable fluctuations. From this, it can be verified that the Dama's high pricing strategy has a relatively negative impact on its sales performance, while, Yongsheng's high pricing strategy created the high performance and value for it.

In general, the price strategy adopted by Dama in practice is contrary to the proposed strategy analyzed by the $\mathrm{O} 2 \mathrm{O}$ model, and the unsatisfactory performance has been achieved. The price strategy actually adopted by Yongsheng is consistent with the proposed strategy of $\mathrm{O} 2 \mathrm{O}$ model analysis, with good performance.

\subsection{Implications on Eenterprises' Pricing Practice}

It can be seen that by correctly evaluating the major factors in the $\mathrm{O} 2 \mathrm{O}$ price model, the resulting pricing conclusions can provide an effective pricing direction for enterprises and provide a reliable basic pricing guidance for enterprises to obtain more profit and market share. In other words, enterprises can efficiently decide a competitive product price by applying the $\mathrm{O} 2 \mathrm{O}$ price model. While, the competitive price can not only ensure the profit of the enterprise, but also meet the perceived value of the consumers, and the relevant value factors and threat factors, and ultimately create the highest benifits for the enterprise.

\section{Discussion and Conclusion}

In general, this study insists on combining macro market with micro market, and combining theory with practice. Furthermore, our results suggest that the study of the new business model of Chinese enterprises must be based on the actual situation of the Chinese market and the current state of transitional economic development in China. Through this study, a strategic model, that can be widely adapted to the pricing of enterprises under the new $\mathrm{O} 2 \mathrm{O}$ business, can be constructed, with a leap from theory to practice. Only theories summed up from the real market economy phenomenon have vitality and practical meaning. In the application and verification of the model, it can be concluded, from the pricing and market profit data provided by the applied enterprise, that the pricing model has strong, which can help companies adjust pricing under fluctuations in value and threat.

Even if the study is not certainly strict or perfect, but from the perspective of the actual market, it should have a certain guiding role in the reality of enterprise development. On the other hand, a study that is out of the market reality, even if it is extremely strict, only gives people a kind of the theoretical enjoyment, cannot play a role in practical application. Based on this point, this study firmly grasps the reality of the market economy of Chinese enterprises in the new situation, tries to pick up the feedback of the model in practice, and does not do the reasoning of course. While, this is not to disparage the contribution of other theoretical researchs to enterprises. On the contrary, this research was established on the basis of previous studies. Although there are important discoveries revealed by 
the study, due to the limited level of authors, there are also limitations, the degree of research refining is not enough, and the theoretical analysis is not comprehensive, which are the elements that should be improved as the future research direction.

\section{References}

Ahn, T., Ryu, S., \& Han, I. (2005). The impact of the online and offline features on the user acceptance of Internet shopping malls. Electronic Commerce Research and Applications, 3, 405-420. https://doi.org/10.1016/j.elerap.2004.05.001

Bhasin, H. (2018). 5 Reasons Pricing Strategy is Increasing in Importance. Retrieved from http://www.marketing91.com/pricing-strategy-increasing-importance

Borden, N. H. (1964). The Concept of the Marketing Mix. Journal of Advertising Research, 2-7. New York, Amercian: Blank.

CAICT. (2017). White Paper on Development of China's Digital Economy. CAICT.

China.org.cn. (2003). Year 200l: Results on Measuring China's Market Economy and the Comparison on Domestic and Overseas Researches. Retrieved from http://www.china.org.cn/english/2003chinamarket/79436.htm

Dolan, R. J., \& Jeuland, A. P. (1981). Experience Curves and Dynamic Demand Models: Implications for Optimal Pricing Strategies. Journal of Marketing, 45, 52-62. New York, Amercian: Blank. https://doi.org/10.2307/1251720

Graham, R. L., Knuth, D. E. O., \& Patashnik. (1994). Concrete Mathematics: A Foundation for Computer Science (2nd ed.). New York, NY: Addison-Wesley Publishing Company.

Grewal, D., Roggeveen, A. L., \& Nordfält, J. (2017). The Future of Retailing. Journal of Retailing, 93(1), 1-6. https://doi.org/10.1016/j.jretai.2016.12.008

He, Z. Cheng, T. C. E., Dong, J. C., \& Wang, S. Y. (2016). Evolutionary location and pricing strategies for service merchants in competitive $\mathrm{O} 2 \mathrm{O}$ markets. European Journal of Operational Research, 254, 595-609. https://doi.org/10.1016/j.ejor.2016.03.030

Kotler, P., \& Keller, K. L. (2016). Marketing Management (pp. 416-424). London, LON: Pearson Education Limited.

Liu, M. Z., \& Feng, W, B. (2018). Opaque distribution channels for service providers with asymmetric capacities: Posted-price mechanisms. International Journal of Production Economics.

Maxxelli Consulting. (2014). O2O: The New Rising Force of China, Maxxelli Consulting. Retrieved from http://www.maxxelli-consulting.com/o2o-new-rising-force-china/

Phillips, R. (2005). Pricing and Revenue Optimization. Redwood City, Redwood City: Stanford University Press.

Porter, M. E. (1998). Competitive Advantage of Nations. London, LON: Freedom Press. https://doi.org/10.1007/978-1-349-14865-3

Porter, M. E. (2004). Competitive Advantage. NewYork, NY: Free Press.

Sánchez-Fernández. R., \& Ángeles Iniesta-Bonillo, M. (2007). The Concept of Perceived Value: A Systematic Review of the Research. Marketing Theory. https://doi.org/10.1177/1470593107083165

Simon, H. (2015). Confessions of the Pricing Man: How Price Affects Everything. Berlin, BER: Springer.

Stanton, W. J. (2008). Marketing in New Era. Beijing, B. J.: Enterprise Management Publish House.

Stern, C. W., \& Deimler, M. S. (2006). The Boston Consulting Group on Strategy. Hoboken: John Wiley \& Sons, Inc..

Sun, Y. F., \& Wei, B. F. (2017). Double 11 E-commerce Transaction Volume Hit a New High. Retrieved from http://tj.people.com.cn/n2/2017/1113/c375366-30915590.html

Tianyancha. (2017). 2017 Annual Report. Guangzhou Dagu Ma Technology Co., Ltd. Retrieved from https://www.tianyancha.com/reportContent/3090915102/2017.

Xiao, S. S., \& Dong, M. (2015). Hidden semi-Markov model-based reputation management system for online to offline (O2O) e-commerce markets. Decision Support Systems, 77, 87-99. https://doi.org/10.1016/j.dss.2015.05.013 